\title{
PENGARUH MODEL PEMBELAJARAN INKUIRI TERBIMBING TERHADAP HASIL BELAJAR IPA DAN SIKAP ILMIAH PADA SISWA KELAS V SD GUGUS I KECAMATAN NUSA PENIDA
}

\author{
Ni Kadek Tri Widani \\ Program Studi Pendidikan Guru Sekolah Dasar, Universitas Pendidikan Ganesha \\ Email: dek3widani@gmail.com \\ Dewa Nyoman Sudana \\ Program Studi Pendidikan Guru Sekolah Dasar, Universitas Pendidikan Ganesha \\ dewasudana245@yahoo.co.id \\ I Gusti Ayu Tri Agustiana \\ Program Studi Pendidikan Guru Sekolah Dasar, Universitas Pendidikan Ganesha \\ Email: igustiayutriagustiana@yahoo.co.id
}

\begin{abstract}
Abstrak
Penelitian ini bertujuan: 1) untuk mengetahui perbedaan yang signifikan hasil belajar IPA antara siswa yang mengikuti pembelajaran dengan menggunakan model pembelajaran inkuiri terbimbing dan siswa yang mengikuti model pembelajaran konvensional, 2) untuk mengetahui perbedaan yang signifikan sikap ilmiah antara siswa yang mengikuti pembelajaran dengan menggunakan model pembelajaran inkuiri terbimbing dan siswa yang mengikuti model pembelajaran konvensional, 3) untuk mengetahui perbedaan hasil belajar IPA dan sikap ilmiah antara siswa yang mengikuti pembelajaran dengan menggunakan model pembelajaran inkuiri terbimbing dan siswa yang mengikuti model pembelajaran konvensional. Penelitian ini merupakan penelitian quasi experiment dengan desain post-test only control group design. Jumlah populasi dalam penelitian ini adalah 87 orang dan sampel penelitian berjumlah 46 orang yang diambil dengan teknik simple random sampling. Data hasil belajar IPA dikumpulkan menggunakan metode tes dengan instrumen tes hasil belajar IPA dan data sikap ilmiah dikumpulkan menggunakan non tes dengan instrumen kuesioner. Data dianalisis dengan statistik deskriptif dan inferensial (MANOVA). Hasil penelitian menunjukkan bahwa: 1) terdapat perbedaan hasil belajar antara siswa yang mengikuti model pembelajaran inkuiri terbimbing dengan siswa yang mengikuti pembelajaran konvensional (Fhitung $=0,007$ $>$ Ftabel $=0,05)$; 2) terdapat perbedaan sikap ilmiah antara siswa yang mengikuti model pembelajaran inkuiri terbimbing dengan siswa yang mengikuti pembelajaran konvensional (Fhitung=0,000 > Ftabel=0,05) dan 3) secara simultan, terdapat perbedaan hasil belajar IPA dan sikap ilmiah siswa yang mengikuti model pembelajaran inkuiri terbimbing dengan siswa yang mengikut pembelajaran konvensional $(\mathrm{F}=0,000 ; \mathrm{p}<0,05)$. Berdasarkan temuan tersebut, dapat disimpulkan bahwa model pembelajaran inkuiri terbimbing berpengaruh positif terhadap hasil belajar IPA dan sikap ilmiah siswa.
\end{abstract}

Kata-kata kunci: inkuiri terbimbing, sikap ilmiah, hasil belajar IPA

\begin{abstract}
The purposes of this research: 1) to find out the significant differences in science learning outcomes between students who take part in learning using guided inquiry learning model and students who follow conventional learning model, 2) to find out significant differences in scientific attitudes between students who take learning using model guided inquiry learning and students who follow conventional learning models, 3) to find out the differences in science learning outcomes and scientific attitudes between students who take part in learning using guided inquiry learning model and students who follow conventional learning model. This research is a quasi experimental study with posttest only control group design. The total population in this study was 87 people and the study sample amounted to 46 people taken by simple random sampling technique. Science learning outcomes data were collected using test methods with science learning outcomes test instrument and scientific attitude data collected using non-test instrument with questionnaires. Data were analyzed by descriptive and inferential statistics (MANOVA). The results of the study show that: 1) there are differences in learning outcomes between students who follow the guided inquiry learning model and students who follow conventional learning $($ Fcount $=0.007>$ Ftable $=0.05) ; 2)$ there are differences in scientific attitudes between students who follow the guided inquiry learning model and students who follow conventional learning $(F c o u n t=0,000>$ Ftable $=0.05)$ and 3) simultaneously, there are differences in science learning outcomes and scientific attitudes of students who follow the learning model guided inquiry with students who follow conventional learning $(F=0,000 ; p<0,05)$. Based on these findings, it can be concluded that the guided inquiry learning model has a positive effect on science learning outcomes and the scientific attitude of students.
\end{abstract}

Key words: inkuiri guided, scientific attitude, science learning outcomes 


\section{Pendahuluan}

Kegiatan penyelenggaraan pendidikan di sekolah, guru dilibatkan sebagai pendidik dan siswa sebagai peserta didik diwujudkan dengan adanya interaksi belajar mengajar. "Kegiatan belajar mengajar yang melahirkan interaksi edukatif guru siswa adalah sebagai suatu proses dalam rangka mencapai tujuan pembelajaran" (Suryani dan Agung, 2013:48). Dalam kegiatan proses pembelajaran diharapkan adanya koordinasi antara guru, siswa, dan lingkungan belajar sehingga tujuan pembelajaran dapat tercapai. Guru hendaknya mampu berperan sebagai fasilitator, motivator, dan membimbing siswa dalam proses pembelajaran. Tujuan pendidikan di SD mencakup pembentukan dasar kepribadian siswa sebagai manusia seutuhnya sesuai dengan tingkat perkembangannya, memberikan pemahaman dasar tentang ilmu pengetahuan dan teknologi sebagai landasan untuk belajar.

Tujuan pendidikan di SD mencakup pembentukan dasar kepribadian siswa sebagai manusia Indonesia seutuhnya sesuai dengan tingkat perkembangan dirinya, pembinaan pemahaman dasar dan seluk-beluk ilmu pengetahuan dan teknologi sebagai landasan untuk belajar. Menurut Susanto (2014), sikap ilmiah merupakan sikap yang harus dimiliki oleh ilmuwan dalam melakukan penelitian dan mengkomunikasikan hasil penelitian. Artinya, sikap ilmiah sangat penting dimiliki, sebab dengan sikap ini ilmuwan akan mampu mencari dan mengembangkan pengetahuan baru dengan kaidah yang tepat. sikap ilmiah harus dikembangkan dalam pembelajaran sains. Hal ini sesuai dengan sikap yang harus dimiliki oleh seseorang ilmuan dalam melakukan penelitian dan mengomunikasikan hasil penelitiannya. Sikap ilmiah dikembangkan melalui kegiatankegiatan siswa dalam pembelajaran IPA pada saat melakukan diskusi, percobaan, simulasi, dan kegiatan proyek di lapangan. Pengembangan sikap ilmiah di sekolah dasar memiliki keseuaian dengan tingkat perkembangan kognitifnya.

Berdasarkan uraian di atas, sikap ilmiah harus dikembangkan pada diri siswa, agar tercapai tujuan pembelajaran IPA secara menyeluruh dan tidak hanya berpatokan pada pengembangan kemampuan aspek kognitif IPA di sekolah dasar hendaknya membuka kesempatan untuk memupuk rasa ingin tahu dan kemampuan belajar yang besar dari anak didik secara alamiah.

Pengelolaan pembelajaran IPA di sekolah, guru harus dapat memberikan pengetahuan peserta didik mengenai konsep-konsep yang terkandung dalam materi IPA. Selain terdapatnya konsep, hendaknya guru juga dapat menerapkan keterampilan proses sains melalui model-model pembelajaran yang dilakukannya. Jadi dalam pelajaran IPA tidak hanya bermanfaat dari segi materinya namun bermanfaat juga terhadap penanaman-penanaman nilai-nilai yang terkandung dalam proses pembelajarannya.

Pendukung dalam pelaksanaan kegiatan pembelajaran adalah sarana dan prasarana. Sarana adalah perlengkapan yang sifatnya dapat digunakan secara langsung. Dalam konsep dasar pengelolaan sarana prasarana pendidikan, sarana berarti perlengkapan yang dapat mendukung dan berhubungan langsung dengan proses pembelajaran. Sementara prasarana adalah fasilitas pokok yang sifatnya mempunyai masa pakai yang cukup lama yang mana dalam konsep dasar pengelolaan sarana prasarana pendidikan, prasarana berarti fasilitas pokok yang digunakan untuk dapat mencapai tujuan dari pendidikan.

Salah satu pendukung yang lainnya adalah faktor evaluasi. Pemberian evaluasi dapat menolong siswa untuk lebih giat dalam belajar dan juga mendorong guru untuk lebih meningkatkan kualitas proses pembelajaran serta untuk mendorong sekolah agar lebih meningkatkan fasilitas dan kualitas manajemen sekolah. Sehubungan dengan hal tersebut, maka di dalam proses pembelajaran dibutuhkan seorang guru yang tidak hanya mampu mengajar dengan baik tetapi juga mampu melakukan evaluasi dengan baik. Kegiatan evaluasi sebagai bagian dari program pembelajaran perlu agar lebih dioptimalkan.

Secara umum pelaksanaan pembelajaran IPA tidak hanya menekankan hasil belajar tetapi juga memperhatikan aspek sikap. Penekanan pada aspek sikap ini dapat dilihat dari penanaman sikap-sikap positif dan sikap ilmiah yang dilakukan guru pada siswa. Guru melakukan penanaman sikap ilmiah pada siswa dengan memperlihatkan contoh sikap ilmiah, penguatan positif pada sikap ilmiah, dan memberikan kesempatan pada siswa untuk memperlihatkan sikap ilmiah.

Menurut Susanto (2014:169) sikap ilmiah harus dikembangkan dalam pembelajaran sains. Hal ini sesuai dengan sikap yang harus dimiliki oleh seorang ilmuan dalam melakukan penelitian dan mengomunikasikan hasil penelitiannya. Sikap ilmiah dikembangkan melalui kegiatan-kegiatan siswa dalam pembelajaran IPA pada saat melakukan diskusi, percobaan, simulasi, dan kegiatan proyek di lapangan. Dari penanaman sikap tersebut, siswa menunjukkan beberapa sikap ilmiah yaitu sikap ingin tahu, sikap respek terhadap data/fakta, sikap berpikir kritis, sikap berpikir terbukadan kerjasama, dan sikap peka terhadap lingkungan sekitar.

Sesuai dengan karakteristik pembelajaran IPA yang menekankan pada proses penemuan sebuah konsep sehingga muncul sikap ilmiah dan siswa dapat mencapai hasil yang lebih baik. Khusunya pada mata pelajaran IPA, pembelajaran ini tidak mengembangkan kemampuan anak untuk dapat berpikir kritis dan sistematis, karena strategi pembelajaran berpikir tidak digunakan secara baik dalam setiap proses pembelajaran di dalam kelas. Pembelajaran IPA pada jenjang pendidikan dasar harus mampu membekali siswa dengan seperangkat kompetensi dan keterampilan serta nilai yang dibutuhkan oleh mereka untuk mengenal diri, lingkungan, dan tantangan masa depan yang akan dihadapi. IPA berhubungan dengan cara mencari tahu tentang alam secara sistematis sehingga IPA bukan hanya penguasaan kumpulan pengetahuan yang berupa fakta, konsep, atau prinsip saja tetapi juga merupakan suatu proses penemuan (Agustiana, 2017:257).

Hasil belajar adalah suatu kemampuan, sikap dan keterampilan yang dapat diperoleh dari siswa setelah ia menerima perlakuan yang diberikan oleh guru sehingga dapat mengkonstruksikan pengetahuan itu dalam kegiatan sehari-hari. Menurut Susanto (2014:12) hasil belajar siswa dipengaruhi oleh dua hal, siswa itu sendiri dan lingkungannya. Pertama, siswa; dalam arti kemampuan berpikir atau tingkah laku intelektual, motivasi, minat, dan kesiapan siswa, baik jasmani maupun rohani. Kedua, lingkungan; yaitu sarana dan prasarana, kompetensi guru, kreativitas guru, sumber-sumber belajar, metode serta dukungan lingkungan, keluarga, dan lingkungan.

Model pembelajaran yang tepat digunakan dalam menunjang kegiatan pembelajaran yang sesuai dengan permasalahan yang ada dan sesuai dengan karakteristik siswa, sehingga akan mendapatkan hasil pembelajaran yang optimal yaitu dengan menggunakan model pembelajaran inkuiri terbimbing.

Menurut Kunandar (dalam Shoimin,2014) menyatakan bahwa pembelajaran inkuiri adalah kegiatan pembelajaran dimana siswa di dorong untuk belajar melalui keterlibatan aktif mereka sendiri dengan konsep-konsep dan prinsip-prinsip, 
dan guru mendorong siswa untuk memiliki pengalaman dan melakukan percobaan yang memungkinkan siswa menemukan prinsip-prinsip untuk diri mereka sendiri.

Model pembelajaran inkuiri terbimbing adalah suatu kegiatan pembelajaran yang dimana guru membimbing siswa dalam menemukan dan mencari sendiri jawaban dari permasalahan yang diberikan. Dengan model ini siswa belajar lebih berorientasi pada bimbingan dan petunjuk dari guru sehingga siswa mampu memahami konsep-konsep pelajaran dengan baik.

Menurut Sari (2017) menyatakan bahwa model pembelajaran inkuiri terbimbing merupakan langkah-langkah pembelajaran yang menekankan proses penyelidikan (investigasi) dalam pemahaman materi dimana siswa juga diharapkan memiliki kemampuan menarik kesimpulan sebagai suatu hasil dari berbagai kegiatan investigasi sederhana dengan dibantu bimbingan dari guru.

Keunggulan model pembelajaran inkuiri terbimbing yaitu dapat membangkitkan motivasi dan gairah belajar peserta didik untuk belajar lebih giat lagi, memberikan peluang untuk berkembang dan maju sesuai dengan kemampuan dan minat masing-masing, membantu peserta didik untuk mengembangkan kesiapan serta penguasaan keterampilan dalam proses kognitif. Hal ini senada dengan hasil penelitian Santiasih (2013) bahwa dibandingkan dengan model pembelajaran konvensional, lebih baik digunakan model pembelajaran inkuiri terbimbing maka sikap ilmiah dan hasil belajar siswa lebih tinggi.

Pembelajaran konvensional merupakan pendekatan pembelajaran yang penerapannya masih berpusat pada guru (teacher centered) dan pembelajaran ini menuntut guru menjadi model yang baik bagi siswanya. Tujuan pembelajaran ini dapat direncanakan bersama oleh guru dan siswa, namun model pembelajaran konvensional lebih berpusat pada guru. Melalui model pembelajaran ini guru menyampaikan materi pembelajaran secara berstruktur dengan harapan materi pelajaran yang disampaikan ini dapat dikuasai siswa dengan baik.

Ciri dari model pembelajaran konvensional adalah (1) peran siswa sebagai objek pendidikan bukan sebagai subjek pendidikan, (2) prinsip-prinsip reaksi difokuskan pada pembentukan perilaku pasif atau menerima saja yang dikatakan guru tanpa ada bantahan atau protes, (3) penyampaian materi dalam pembelajaran konvensional lebih banyak dilakukan ceramah, tanya jawab, penugasan yang berlangsung secara terus-menerus, dan guru tetap berperan sebagai sumber informasi. Kegiatan seperti ini dapat membosankan dan melemahkan kegiatan siswa dalam belajar, (4) sistem dukungan model pembelajaran konvensional berfokus pada pemanfaatan fasilitas yang tersedia yang jumlahnya masih sangat terbatas, misalnya buku-buku teks.

Mengingat masalah tersebut sangat penting, maka dilakukan penelitian dengan tujuan untuk mengetahui perbedaan yang singnifikan pada hasil belajar IPA dan sikap ilmiah antara siswa yang mengikuti pembelajaran menggunakan model inkuiri terbimbing dan siswa yang mengikuti pembelajaran secara konvensional pada siswa kelas V SD Negeri di Gugus I Kecamatan Nusa Penida Kabupaten Klungkung tahun pelajaran 2018/2019.

\section{Metode}

Penelitian ini merupakan penelitian eksperimen semu (quasi experiment). Hal ini dikarenakan penelitian ini dilaksanakan di suatu institusi sekolah sehingga secara teknis tidak memungkinkan untuk mengontrol semua variabel secara ketat. dengan rancangan post-test only control group design. Adapun rancangan dari penelitian ini adalah post-test only control group design. Rancangan penelitian ini dapat digambarkan dalam tabel 1.

Tabel 1. Rancangan Penelitian

\begin{tabular}{ccc}
\hline Kelompok & Treatment & Post-test \\
\hline Eksperimen & $\mathrm{X}$ & $\mathrm{O}_{1}$ \\
Kontrol & - & $\mathrm{O}_{2}$ \\
\hline
\end{tabular}

Keterangan:

X: Perlakuan berupa model pembelajaran inkuiri terbimbing.

-: Perlakuan berupa pembelajaran model konvensional.

O1: post-test untuk kelas eksperimen.

O2: post-test untuk kelas kontrol.

Prosedur yang dilakukan dalam penelitian ini terdiri dari (1) menentukan sekolah yang digunakan sebagai tempat penelitian. Sekolah yang dipilih adalah SD di Gugus I Kecamatan Nusa Penida. Dengan melakukan wawancara, pencatatan dokumen, dan observasi sehingga diperoleh informasi yang dibutuhkan dalam penelitian, (2) penentuan populasi dan sampel penelitian. Populasi dari penelitian ini adalah seluruh siswa kelas V SD Gugus I Kecamatan Nusa Penida yang terdiri dari 4 kelas dan berjumlah 87 orang siswa. Sampel yang digunakan adalah keseluruhan adalah SD Negeri 2 Batununggul dan SD Negeri 3 Batununggul. Penentuan sampel dilakukan melalui teknik simple random sampling, yakni pengundian tahap pertama. Kemudian untuk menentukan kelompok eksperimen dan kelompok kontrol melalui pengundian tahap kedua, (3) menyusun dan merancang perangkat pembelajaran berupa RPP dan soal-soal sesuai dengan model pembelajaran yang digunakan, serta menyusun tes hasil belajar dan kuesioner, (4) mengkonsultasikan instrumen dengan melakukan uji judges, (5) merevisi instrumen penelitian sesuai dengan hasil uji judges yang telah dilakukan dengan menguji tingkat kesukaran, daya beda, validitas, dan reliabilitas, (6) memberikan sosialisasi dan penjelasan kepada guru mata pelajaran IPA pada kelas eksperimen tentang model pembelajaran yang akan diterapkan yaitu model pembelajaran inkuiri terbimbing, (7) melakukan pembelajaran pada kelompok sampel yang telah ditentukan, yaitu pembelajaran dengan model pembelajaran inkuiri 
terbimbing pada kelas eksperimen dan pembelajaran konvensional pada kelas kontrol, (8) mengadakan post-test pada masing-masing kelas berupa tes hasil belajar dan memberikan kuesioner, (9) menganalisis data hasil penelitian dan menguji hipotesis penelitian, (10) menyusun laporan.

Populasi penelitian ini adalah siswa kelas V SD Gugus I Kecamatan Nusa Penida Kabupaten Klungkung dengan jumlah 87 siswa, dibagi menjadi 4 SD yaitu (1) SD Negeri 1 Batununggul 24 siswa, (2) SD Negeri 2 Batununggul 21 siswa, (3) SD Negeri 3 Batununggul 25 siswa, (4) SD Negeri 4 Suana 17 siswa. Untuk mengetahui kesetaraan kemampuan akademik pada populasi penelitian maka dilakukan uji ANAVA terhadap data hasil belajar IPA siswa kelas V.

Data hasil belajar IPA pada siswa SD kelas V tersebut dilakukan uji kesetaraan yang dianalisis dengan uji ANAVA. Dari hasil uji ANAVA yang dilakukan diperoleh ke-4 SD yang ada di SD Gugus I Kecamatan Nusa Penida memiliki kemampuan akademik setara. Langkah selanjutnya ialah melakukan teknik random sampling terhadap keempat sekolah tersebut. Sehingga diperoleh SD Negeri 2 Batununggul sebagai kelompok eksperimen dan SD Negeri 3 Batununggul sebagai kelompok kontrol. Kelompok eksperimen diberika model pembelajaran inkuiri terbimbing sedangkan kelompok kontrol diberikan model pembelajaran konvensional.

Data yang dianalisis dalam penelitian ini adalah hasil belajar IPA ranah kognitif yang dikumpulkan melalui tes pilihan ganda sedangkan data sikap ilmiah dikumpulkan melalui kuesioner. Tes tersebut telah di uji coba lapangan, sehingga teruji validitas dan reliabilitasnya. Hasil tes uji lapangan tersebut selanjutnya diberikan kepada siswa kelas eksperimen dan kontrol sebagai post-test. Analisis data yang digunakan dalam penelitian ini yaitu analisis statistik deskriptif yang dianalisis dengan menghitung nilai mean, median, modus, standar deviasi, varian, skor maksimum, dan skor minimum dan uji prasyarat yang dianalisis dengan uji normalitas, uji homogenitas varians, uji korelasi antar variabel terikat dan uji hipotesis yang menggunakan uji MANOVA.

\section{Hasil dan Pembahasan}

Data hasil penelitian dianalisis sehingga diperoleh mean, median, modus, serta standar deviasi dari tiap-tiap kelompok data disajikan seperti pada Tabel 2.

Tabel 2. Ringkasan Analisis Hasil Belajar dan Sikap Ilmiah IPA Kelompok Eksperimen dan Kelompok Kontrol

\begin{tabular}{ccccc}
\hline Hasil Analisis & $\begin{array}{c}\text { Hasil Belajar } \\
\text { Kelompok } \\
\text { Eksperimen }\end{array}$ & $\begin{array}{c}\text { Hasil Belajar } \\
\text { Kelompok Kontrol }\end{array}$ & $\begin{array}{c}\text { Sikap Ilmiah Kelompok } \\
\text { Eksperimen }\end{array}$ & $\begin{array}{c}\text { Sikap Ilmiah Kelompok } \\
\text { Kontrol }\end{array}$ \\
\hline N & 21 & 25 & 21 & 124,48 \\
Mean & 21,48 & 18,56 & 124,06 & 116,80 \\
Median & 21,75 & 18,45 & 123,93 & 116,50 \\
Modus & 22 & 18,65 & 5,68 & 32,63 \\
Standar Deviasi & 3,64 & 3,34 & 137 & 11,75 \\
Varian & 13,26 & 11,17 & 125 \\
Skor Maksimal & 28 & 26 & 106 \\
\hline
\end{tabular}

Berdasarkan tabel 2 terlihat bahwa, rata-rata skor hasil belajar IPA siswa yang menggunakan model pembelajaran inkuiri terbimbing lebih tinggi daripada rata-rata skor hasil belajar IPA siswa yang menggunakan model pembelajaran konvensionel. Begitu pula dengan rata-rata skor sikap ilmiah siswa yang menggunakan model pembelajaran inkuiri terbimbing lebih tinggi daripada rata-rata skor sikap ilmiah siswa yang menggunakan model pembelajaran konvensional.

Sebelum melakukan pengujian hipotesis, terlebih dahulu dilakukan uji prasyarat analisis yaitu dengan uji normalitas, uji homogenitas varians, dan uji korelasi antar variabel terikat. Untuk menguji hipotesis pertama menggunakan bantuan SPSS 25.0 yang hasilnya ditunjukkan seperti pada Tabel 3. 
Tabel 3 Ringkasan Hasil Uji Hipotesis I dan II

\begin{tabular}{|c|c|c|c|c|c|c|c|c|}
\hline \multirow[b]{2}{*}{ Source } & \multicolumn{8}{|c|}{ Tests of Between-Subjects Effects } \\
\hline & Dependent Variable & $\begin{array}{l}\text { Type III Sum } \\
\text { of Squares }\end{array}$ & df & Mean Square & $\mathrm{F}$ & Sig. & $\begin{array}{l}\text { Noncent. } \\
\text { Parameter }\end{array}$ & $\begin{array}{l}\text { Observed } \\
\text { Power }^{\circ}\end{array}$ \\
\hline \multirow[t]{2}{*}{ Corrected Model } & HASIL_BELANAR & $97.058^{a}$ & 1 & 97.058 & 8.006 & .007 & 8.006 & .790 \\
\hline & SIKAP_ILMIAH & $672.501^{\mathrm{b}}$ & 1 & 672.501 & 21.027 & .000 & 21.027 & .994 \\
\hline \multirow[t]{2}{*}{ Intercept } & HASIL_BELAJAR & 18293.928 & 1 & 18293.928 & 1509.066 & .000 & 1509.066 & 1.000 \\
\hline & SIKAP_ILMIAH & 664401.197 & 1 & 664401.197 & 20773.779 & .000 & 20773.779 & 1.000 \\
\hline \multirow{2}{*}{ KELOMPOK } & HASIL_BELANAR & 97.058 & 1 & 97.058 & 8.006 & .007 & 8.006 & .790 \\
\hline & SIKAP_ILMIAH & 672.501 & 1 & 672.501 & 21.027 & .000 & 21.027 & .994 \\
\hline \multirow[t]{2}{*}{ Error } & HASIL_BELAJAR & 533.398 & 44 & 12.123 & & & & \\
\hline & SIKAP_ILMIAH & 1407.238 & 44 & 31.983 & & & & \\
\hline \multirow[t]{2}{*}{ Total } & HASIL_BELANAR & 18831.000 & 46 & & & & & \\
\hline & SIKAP_ILMIAH & 667844.000 & 46 & & & & & \\
\hline \multirow[t]{2}{*}{ Corrected Total } & HASIL_BELAJAR & 630.457 & 45 & & & & & \\
\hline & SIKAP_ILMIAH & 2079.739 & 45 & & & & & \\
\hline
\end{tabular}

Berdasarkan tabel 3 dapat diketahui bahwa, hasil belajar IPA yang dibelajarkan dengan model pembelajaran inkuiri terbimbing dan model pembelajaran konvensional menghasilkan taraf signifikasi hasil belajar $0,007<0,05$, yang artinya $\mathrm{H} 0$ ditolak dan H1 diterima. Hal ini menunjukkan bahwa "terdapat perbedaan yang signifikan hasil belajar IPA antara siswa yang dibelajarkan dengan menggunakan model pembelajaran inkuiri terbimbing dengan siswa yang dibelajarkan menggunakan model pembelajaran konvensional".

Hipotesis kedua diuji dengan menggunakan bantuan SPSS 25. Hasil analisisnya disajiikan seperti pada tabel 3 di atas. Dapat diketahui bahwa, sikap ilmiah siswa yang dibelajarkan dengan model pembelajaran inkuiri terbimbing dan model pembelajaran konvensional menghasilkan taraf signifikansi sikap ilmiah sebesar $0,000<0,005$, yang artinya H0 ditolak dan H1 diterima. Hal ini menunjukkan bahwa "terdapat perbedaan yang signifikan sikap ilmiah antara siswa yang dibelajarkan dengan menggunakan model pembelajaran inkuiri terbimbing dengan siswa yang dibelajarkan menggunakan model pembelajaran konvensional".

Tabel 4 Ringkasan Hasil Analisis MANOVA

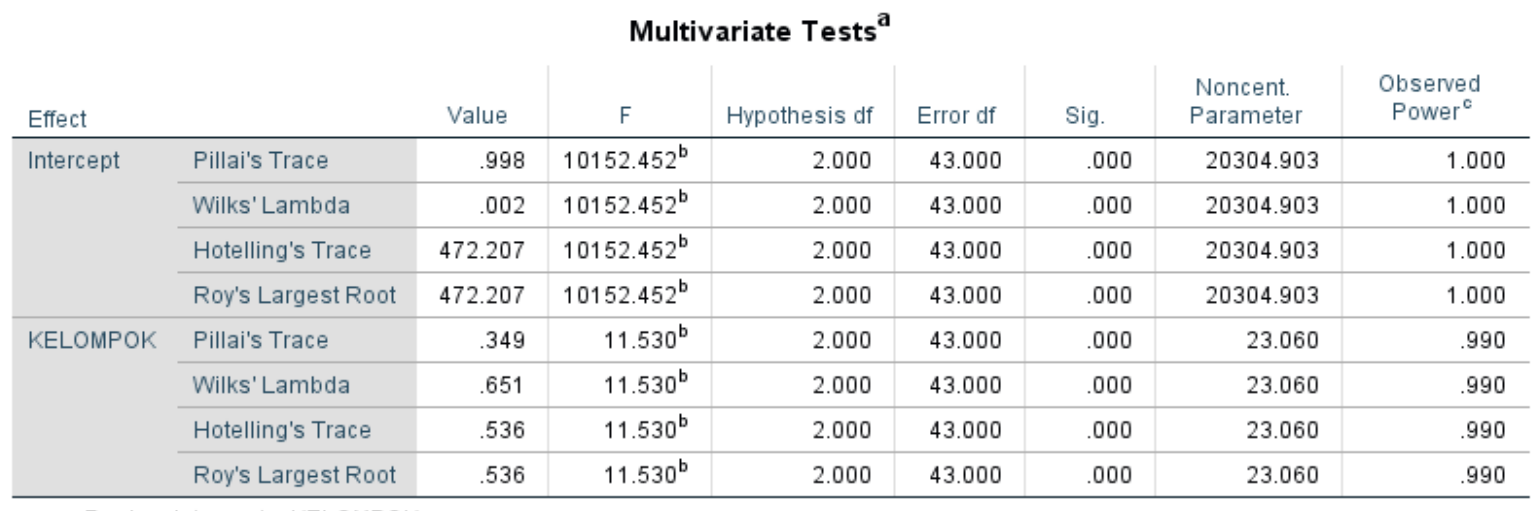

Berdasarkan ringkasan hasil uji Multivariate diperoleh hasil perhitungan nilai-nilai statistik Pillai's Trace, Wilks'Lamda, Hotelling's Trace, dan Roy's Largest Root masing-masing dengan nilai $F=11,530$ dan $p<0,05$. Dengan demikian dapat disimpulkan untuk hipotesis yang ketiga. Bahwa "terdapat perbedaan yang signifikan hasil belajar dan sikap ilmiah antara siswa yang dibelajarkan dengan menggunakan model pembelajaran inkuiri terbimbing dengan siswa yang dibelajarkan menggunakan model pembelajaran konvensional". Artinya HO ditolak, yang berarti terdapat perbedaan yang signifikan hasil belajar dan sikap ilmiah antara siswa yang dibelajarkan dengan menggunakan model pembelajaran inkuiri terbimbing dengan siswa yang dibelajarkan menggunakan model pembelajaran konvensional.

Berdasarkan hasil analisis uji MANOVA, maka diperoleh hasil belajar IPA dan sikap ilmiah yang belajar dengan model pembelajaran inkuiri terbimbing lebih baik daripada hasil belajar IPA dan sikap ilmiah siswa belajar dengan model pembelajaran konvensional.

Hasil analisis hipotesis pertama menujukkan bahwa, hasil belajar IPA dengan model pembelajaran inkuiri terbimbing lebih baik dari pada hasil belajar IPA dengan model pembelajaran kovensional. Hal ini disebabkan karena model pembelajaran inkuiri terbimbing dalam proses pembelajaran IPA dapat memberikan peluang kepada siswa untuk berpartisipasi aktif dalam proses pembelajaran. Siswa belajar sambil melakukan sendiri dalam menemukan konsep yang dipelajari, berdasarkan masalah yang ada di lingkungan sekitar. Siswa akan memperoleh pengalaman lebih bermakna dan lebih kuat melekat dalam pikiran mereka. Hasil ini sejalan dengan penelitian Antara (2017) yang menunjukan bahwa terdapat perbedaan hasil belajar IPA antara siswa yang mengikuti pembelajaran menggunakan model inkuiri terbimbing dengan siswa yang mengikuti pembelajaran secara konvensional. Siswa yang menggunakan model pembelajaran inkuiri terbimbing memperoleh hasil belajar yang lebih tinggi. Model pembelajaran inkuiri terbimbing mampu mendorong peserta didik untuk berpikir secara aktif dan bekerja atas inisiatifnya sendiri dalam merumuskan hipotesis dan memecahkan masalah yang dihadapinya. Berdasarkan pembahasan di atas maka model pembelajaran inkuiri terbimbing berpengaruh dalam peningkatan hasil belajar IPA siswa kelas V SD Gugus I Kecamatan Nusa Penida. 
Hasil analisis hipotesis kedua menunjukkan bahwa sikap ilmiah siswa pada pembelajaran IPA dengan model pembelajaran inkuiri terbimbing lebih baik daripada sikap ilmiah siswa pada pembelajaran IPA dengan model pembelajaran konvensional. Dewi et al (2013) yang berjudul "Pengaruh Model Pembelajaran Inkuiri Terbimbing terhadap Sikap Ilmiah dan Hasil Belajar IPA". Hasil penelitiannya menunjukkan bahwa, (1) terdapat perbedaan sikap ilmiah dan hasil belajar IPA antara siswa yang belajar dengan menggunakan model pembelajaran inkuiri terbimbing dan model pembelajaran konvensional, (2) terdapat perbedaan sikap ilmiah dalam pembelajaran IPA secara signifikan antara siswa yang belajar dengan menggunakan model pembelajaran inkuiri terbimbing dan model pembelajaran konvensional, dan (3) terdapat perbedaan hasil belajar secara signifikan antara siswa yang belajar dengan menggunakan model pembelajaran inkuiri terbimbing dan model pembelajaran konvensional. Pembelajaran menggunakan model pembelajaran inkuiri terbimbing lebih baik dan efektif untuk menumbuhkan sikap ilmiah peserta didik. Sikap ilmiah bisa ditumbuhkan dengan model pembelajaran inkuiri terbimbing, yang dalam tahapan pembelajarannya terdapat proses menemukan sendiri. Berbeda halnya dengan model pembelajaran konvensioal, yang pembelajarannya masih bersifat teacher center, sehingga siswa tidak dapat terlibat aktif dalam pembelajaran dan tidak mendapatkan kesempatan untuk menemukan sendiri pengetahuannya. Berdasarkan pembahasan di atas, maka model pembelajaran inkuiri terbimbing mempengaruhi sikap ilmiah siswa dalam pembelajaran IPA, sehingga terdapat perbedaan yang signifikan antara sikap ilmiah siswa yang mengikuti pembelajaran dengan model pembelajaran inkuiri terbimbing dengan siswa yang mengikuti model pembelajaran konvenional.

Hasil analisis hipotesis ketiga menunjukkan bahwa, hasil belajar IPA dan sikap ilmiah dengan model pembelajaran inkuiri terbimbing lebih baik daripada hasil belajar IPA dan sikap ilmiah dengan model pembelajaran konvensional. Model pembelajaran inkuiri terbimbing didasarkan pada teori belajar penemuan dimana siswa aktif mengkonstruksikan pengetahuannya berdasarkan tahapan model pembelajaran inkuiri terbimbing. Pada tahap elisitasi gagasan awal siswa, guru menggali gagasan awal siswa dengan mengajukan pertanyaan. Guru juga membimbing siswa untuk mampu menimbulkan pertanyaan-pertanyaan dari pengalaman-pengalaman siswa dalam kehidupan sehari-hari yang berkaitan dengan materi struktur bumi yang dipelajari. Siswa juga mengajukan hipotesis berdasarkan permasalahan yang diberikan oleh guru. Pada tahap pengujian gagasan awal, siswa melakukan pengamatan dan proses penyelidikan untuk menjawab dan membuktikan hipotesis yang telah mereka buat. Melalui kegiatan tersebut siswa akan berperan aktif untuk melakukan dan menemukan sendiri suatu konsep melalui bimbingan guru, memecahkan permasalahan yang diberikan melalui diskusi dengan sesama kelompoknya. Pada tahap negosiasi makna, siswa melakuka diskusi bersama kelompoknya mengenai pengamatan yang telah dilakukan. Kegiatan ini dilakukan dengan bimbingan yang diberikan oleh guru, sehingga proses diskusi berjalan dengan baik dan siswa akan mendapatkan pengalaman belajar. Pada tahap penerapan konsep pada situasi baru, siswa akan menerapkan konsep-konsep yang dimilikinya dalam memecahkan masalah yang diberikan. Pembelajaran yang seperti ini dapat memberikan suasana baru pada kegiatan pembelajaran. Tahap pembuatan kesimpulan dan refleksi, setelah selesai memecahkan masalah yang diberikan siswa membuat kesimpulan terhadap pengamatan yang telah dilakukan. Dengan menerapkan tahapan dari model pembelajaran inkuiri terbimbing maka siswa akan bersemangat untuk mencari jawaban yang diajukan oleh guru dan siswa juga akan mengembangkan sikap ilmiah mereka. Dengan demikian pemahaman dan ingatan siswa terhadap suatu konsep IPA menjadi kuat dan bertahan lama. Hal ini akan berpengaruh positif terhadap sikap ilmiah serta hasil belajar siswa. Hal ini didukung oleh hasil penelitian yang dilakukan oleh Santiasih (2013) penelitian ini menunjukkan bahwa, 1) terdapat perbedaan sikap ilmiah dalam pembelajaran IPA secara signifikan antara siswa yang mengikuti model pembelajaran inkuiri terbimbing dengan model pembelajaran konvensional, (2) terdapat perbedaan hasil belajar IPA secara signifikan antara siswa yang mengikuti model pembelajaran inkuiri terbimbing dengan model pembelajaran konvensional, dan (3) terdapat perbedaan sikap ilmiah dan hasil belajar IPA antara siswa yang mengikuti model pembelajaran inkuiri terbimbing dengan model pembelajaran konvensional.

Berdasarkan temuan-temuan dalam penelitian ini, maka model pembelajaran inkuiri terbimbing lebih baik dibandingkan dengan menggunakan model pembelajaran konvensional dalam hal meningkatkan hasil belajar IPA dan sikap ilmiah siswa.

\section{Simpulan}

Hasil penelitian dapat disimpulkan sebagai berikut. Pertama, Terdapat perbedaan yang signifikan hasil belajar IPA antara siswa yang mengikuti pembelajaran dengan menggunakan model pembelajaran inkuiri terbimbing dan siswa yang mengikuti model pembelajaran konvensional pada siswa kelas V SD Gugus I Kecamatan Nusa Penida. Hasil belajar IPA siswa yang dibelajarkan dengan menggunakan model pembelajaran inkuiri terbimbing lebih baik dibandingkan dengan siswa yang dibelajarkan menggunakan model pembelajaran konvensional.

Kedua, terdapat perbedaan yang signifikan sikap ilmiah antara siswa yang mengikuti pembelajaran dengan menggunakan model pembelajaran inkuiri terbimbing dan siswa yang mengikuti model pembelajaran konvensional pada siswa kelas V SD Gugus I Kecamatan Nusa Penida. Sikap ilmiah siswa yang dibelajarkan dengan menggunakan model pembelajaran inkuiri terbimbing lebih baik dibandingkan dengan siswa yang dibelajarkan menggunakan model pembelajaran konvensional.

Ketiga, terdapat perbedaan hasil belajar IPA dan sikap ilmiah antara siswa yang mengikuti pembelajaran dengan menggunakan model pembelajaran inkuiri terbimbing dan siswa yang mengikuti model pembelajaran konvensional pada siswa kelas V SD Gugus I Kecamatan Nusa Penida. Hasil belajar IPA dan sikap ilmiah siswa yang dibelajarkan dengan menggunakan model pembelajaran inkuiri terbimbing lebih baik dibandingkan dengan siswa yang dibelajarkan menggunakan model pembelajaran konvensional.

Berdasarkan hasil penelitian, maka dapat diajukan beberapa saran sebagai berikut. Kepada guru disarankan menerapkan model pembelajaran inkuiri terbimbing untuk meningkatkan hasil belajar IPA dan sikap ilmiah. Guru juga dapat menerapkan model inkuiri terbimbing pada materi IPA atau mata pelajaran lain yang memiliki karakteristik sama dengan materi dalam penelitian ini. Kepada sekolah disarankan membuat kebijakan untuk menerapkan model pembelajaran inkuiri terbimbing dalam pembelajaran IPA yang berkaitan dengan materi percobaan atau eksperimen dalam meningkatkan hasil belajar. Kepada peneliti lain perlu diadakan penelitian yang sejenis dengan melibatkan sampel yang lebih banyak, sehingga dapat meningkatkan hasil belajar IPA dan sikap ilmiah khususnya dalam mata pelajaran IPA. 


\section{Daftar Pustaka}

Agustiana, I. G. A. T dan I. Nym. Tika. 2017. Konsep dasar IPA aspek fisika dan kimia. Yogyakarta: Penerbit Ombak. Antara. I. Gd. W. 2017. "Pengaruh Model Pembelajaran Inkuiri Terbimbing terhadap Hasil Belajar IPA Siswa Kelas V SD". e-journal pendidikan universitas pendidikan ganesha program studi PGSD (volume 5 Tahun 2017).

Dewi, N.L., N.Dantes, I W. Sadia. 2013. "Pengaruh Model Pembelajaran Inkuiri Terbimbing terhadap Sikap Ilmiah dan Hasil Belajar IPA". E-Journal Program Pascasarjana Universitas Pendidikan Ganesha. Vol. 3. Tersedia pada http://oldpasca.undiksha.ac.id/e-journal/index.php/jurnal_pendas/article/ view/ 512. Diakses pada 23 Mei 2019.

Shoimin, A. 2014. 68 model pembelajaran inovatif dalam kurikulum 2013. Yogyakarta: AR-RUZZ MEDIA.

Sari, N. L. B. A. 2017. "Pengaruh model pembelajaran inkuiri terbimbing berbantuan media audio-visual terhadap kompetensi pengetahuan IPA siswa kelas IV”. e-journal pendidikan universitas pendidikan ganesha program studi PGSD (volume 5 Tahun 2017).

Satiasih, N.L., A.A.I.N. Marhaeni, I N. Tika. 2013. "Pengaruh Model Pembelajaran Inkuiri Terbimbing terhadap Sikap Ilmiah dan Hasil Belajar IPA Siswa Kelas V No. 1 Kerobokan Kecamatan Kuta Utara Kabupaten Badung Tahun Pelajaran 2013/2014”. E-journal Pascasarjana Universitas Pendidikan Ganesha. Vol.3. tersedia pada https://media.neliti.com/media/publications/122294-ID-pengaruh-model-pembelajaran-inkuiri-terb.pdf. Diakses pada 23 Mei 2019.

Susanto, A. 2014. Teori belajar \& pembelajaran di sekolah dasar. Jakarta: Kencana.

Suryani, N dan L. Agung. 2013. Strategi belajar mengajar. Yogyakarta: Penerbit Ombak (Anggota IKAPI). 